\title{
Platelet indices in children with sepsis and their relation to the outcome
}

\author{
Subbiah M Sriram ${ }^{1}$, Shrikiran Aroor ${ }^{1}$, Pushpa G Kini ${ }^{1}$, ${ }^{*}$ Shravan Kanaparthi ${ }^{1}$, Kalyan Chakravarthy \\ Konda ${ }^{1}$
}

Sri Lanka Journal of Child Health, 2018; 47(4): 301-305

\begin{abstract}
Introduction: Sepsis is a major causes of mortality and morbidity among children. An effective and accurate biochemical marker is needed which can support or exclude the diagnosis of sepsis.
\end{abstract}

Objective: To study the platelet indices in children with sepsis and their relation to the outcome

Method: A prospective observational study was conducted in a tertiary care centre from southern India from October 2015 to July 2017. Children aged 1 month to 18 years of age with sepsis, as per the definition of International Paediatric Sepsis Consensus Conference 2005, were included in the study. Children with no infection were taken as controls. Children with haematological malignancies, known platelet disorders, haemolytic anaemia and children with a history of recent blood transfusions or splenectomy were excluded from the study. History and physical examination findings were noted in a pre-designed proforma. Platelet indices were measured using an automated blood counter, Beckman Coulter LH780 series. Counts done at the time of admission and prior to discharge or death were taken for analysis. Mean platelet volume (MPV), platelet distribution width (PDW) and plateletcrit (PCT) values were compared with standard normal values. Severity of thrombocytopenia was classified as mild $(50,000-$ $150,000 / \mathrm{cu} \mathrm{mm})$, moderate $(20,000-50,000 / \mathrm{cu} \mathrm{mm})$ and severe $(<20,000$ or $<50,000 / \mathrm{cu} \mathrm{mm}$ with clinical bleeding) for the study purpose. Mean and median were used for data with normal and nonnormal distribution. Mann-Whitney was used for analysis of continuous variables. Chi-square was used for categorical variables. Analysis of mean was done using independent t-test. Data was analysed using SPSS version 21. Study protocol was approved by Institutional Ethics Committee (IEC No: 595/2015).

${ }^{1}$ Kasturba Medical College, Manipal, Karnataka,
India
${ }^{*}$ Correspondence: shravan.1354@gmail.com
(Received on 06 December 2017: Accepted after
revision on 19 January 2018)
The authors declare that there are no conflicts of
interest
Personal funding was used for the project.
Open Access Article published under the Creative

Commons Attribution CC-BY (CC)
Results: A total of 191 children with sepsis were enrolled in the study of which 40 were excluded. Thrombocytopenia was observed among 67.5\% $(102 / 151)$ of the study population with sepsis. The difference in platelet indices between cases and controls were found to be statistically significant. Mortality rate in the present study was $27.8 \%$ $(42 / 151)$. Platelet count $(p=0.003)$ and plateletcrit $(p=0.004)$ were significantly low among nonsurvivors when compared to survivors with sepsis. Among the children who had thrombocytopenia prior to discharge, severity of thrombocytopenia showed significant relation with the outcome of children with sepsis $(\mathrm{p}=0.006)$.

Conclusions: In the present study, plateletcrit, mean platelet volume, platelet distribution width and platelet count showed statistically significant relation in children with sepsis when compared to controls. With regard to predicting mortality, platelet count and plateletcrit showed statistically significant lower values among non survivors when compared to survivors.

DOI: http://dx.doi.org/10.4038/sljch.v47i4.8589

(Key words: Sepsis, thrombocytopenia, paediatrics, mean platelet volume)

\section{Introduction}

Sepsis is one of the major causes of mortality and morbidity among children ${ }^{1,2}$. Diagnosis of sepsis in children is difficult as the clinical signs in children are variable at the start of the infection, microbiological culture results are expected only after 48-72 hours and false negatives are common. An effective and accurate biochemical marker is needed which can support or exclude the diagnosis of sepsis. Sepsis is characterized by thrombocytopenia and platelet dysfunction due to underlying mechanisms which are not yet clearly understood. It has been shown that thrombocytopenia is an independent predictor of mortality in children with sepsis in the intensive care unit ${ }^{3}$. Platelet indices are markers of platelet activation. Among the platelet indices, mean platelet volume (MPV), and platelet distribution width (PDW) are usually dependent on platelet morphology and proliferation kinetics ${ }^{4}$. MPV is inversely related to platelet counts ${ }^{5}$. Vander Lelie $e t$ al suggested that an increased MPV could be associated with invasive infections ${ }^{4}$. Under physiological conditions, MPV and PDW are 
directly related. When there is an increase in PDW, MPV increases ${ }^{4}$.

\section{Objective}

To study the platelet indices in children with sepsis and their relation to the outcome

\section{Method}

A prospective observational study was conducted in a tertiary care centre from southern India from October 2015 to July 2017. Children aged 1 month to 18 years of age with sepsis, as per the definition of International Paediatric Sepsis Consensus Conference 2005 i.e. Systemic Inflammatory Response Syndrome in the presence of / as a result of suspected / proven infection, were included in the study. Children with no infection were taken as controls. Children with haematological malignancies, known platelet disorders, haemolytic anaemia and with a history of recent blood transfusions (packed red blood cells and platelets) and splenectomy were excluded from the study.

History and physical examination findings were noted down in a pre-designed proforma. Two $\mathrm{ml}$ of EDTA blood was collected through a clean venipuncture from children with sepsis and samples were sent immediately to clinical laboratory. Platelet indices were measured using an automated blood counter, Beckman Coulter LH780 series. Counts done at the time of admission and prior to discharge or mortality were taken for analysis. Children of comparable age groups admitted for elective surgeries with no infections were selected as controls and platelet indices done prior to surgery were taken for analysis. Mean platelet volume (MPV), platelet distribution width (PDW), plateletcrit (PCT) and platelet values were compared with standard normal values ${ }^{6-8}$. Severity of thrombocytopenia was classified as mild $(50,000-150,000 / \mathrm{cu} \mathrm{mm})$, moderate $(20,000$ $50,000 / \mathrm{cu} \mathrm{mm})$ and severe $(<20,000$ or $<50,000 / \mathrm{cu}$ $\mathrm{mm}$ with clinical bleeding) for the study purpose.

Statistical analysis: Mean and median were used for data with normal and non-normal distribution. Mann-Whitney was used for analysis of continuous variables. Chi-square was used for categorical variables. Analysis of mean was done using independent t-test. Data was analysed using SPSS version 21.

Study protocol was approved by Institutional Ethics Committee (IEC No: 595/2015).

\section{Results}

The study flow chart is shown in Figure 1.

Total number of children enrolled in the study ( $n=391)$

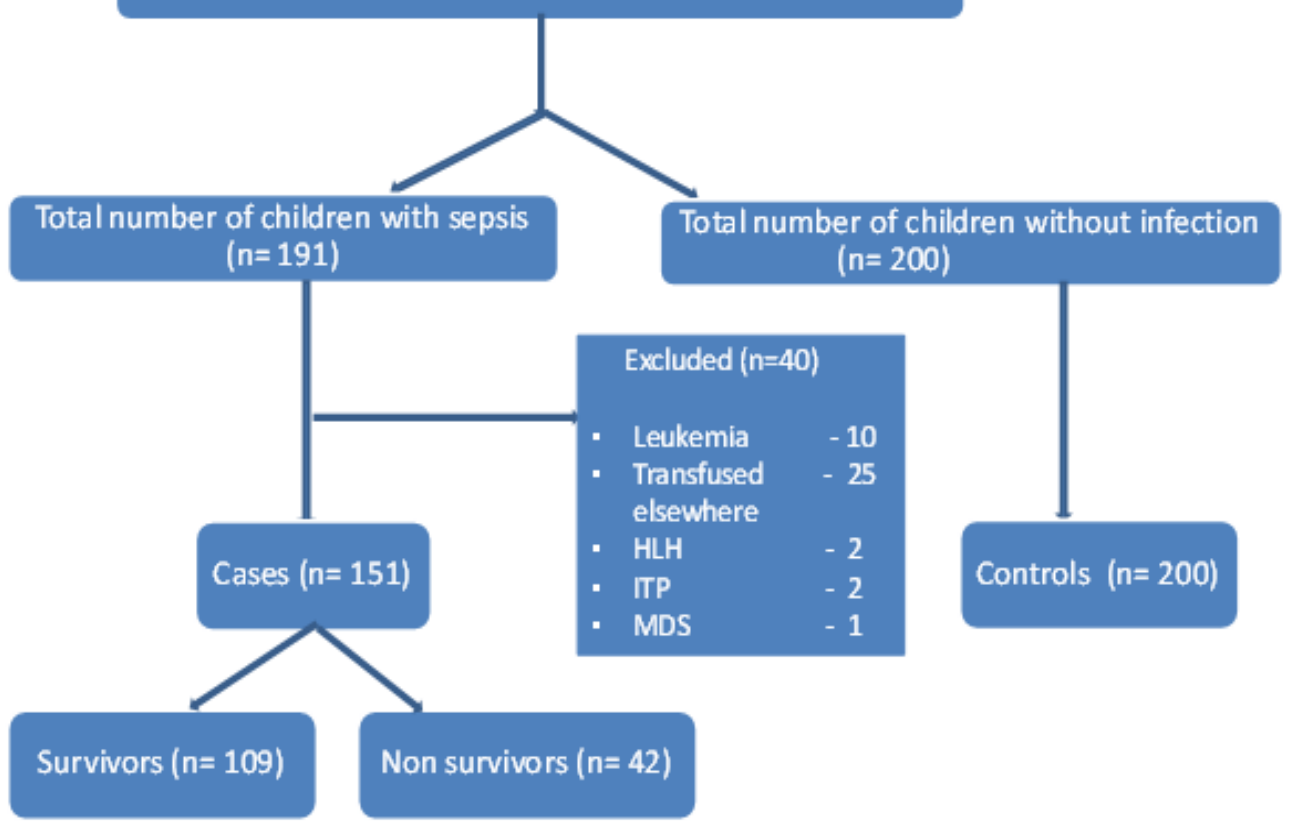

Figure 1: Study flow Chart

A total of 151 children with sepsis and 200 controls were included in the study (Figure 1). Forty children with sepsis were excluded (Figure 1). Among the 151 children with sepsis included in the study, $76(50.4 \%)$ satisfied the criteria for sepsis,
$39(25.8 \%)$ for septic shock and $36(23.8 \%)$ for severe sepsis. Mortality rate in the sepsis group was $27.8 \%(n=42)$. The baseline characteristics and laboratory parameters of cases and controls are shown in Table 1 
Table 1: Baseline characteristics and laboratory parameters of cases and controls

\begin{tabular}{|c|c|c|c|}
\hline Baseline characteristics & Cases $(n=151)$ & Controls $(n=200)$ & $p$ value \\
\hline $\begin{array}{l}\text { Gender } \\
\text { Male No. }(\%) \\
\text { Female No. }(\%)\end{array}$ & $\begin{array}{l}91(60.3) \\
60(39.7)\end{array}$ & $\begin{array}{l}121(60.5) \\
79(39.5)\end{array}$ & \\
\hline $\begin{array}{l}\text { Age } \\
1 \text { month to } \leq 5 \text { years No. }(\%) \\
>5 \text { years to } \leq 12 \text { years No. }(\%) \\
>12 \text { years to }<18 \text { years No. }(\%)\end{array}$ & $\begin{array}{l}72(47.7) \\
34(22.5) \\
45(29.8)\end{array}$ & $\begin{array}{l}96(48.0) \\
48(24.0) \\
56(28.0)\end{array}$ & \\
\hline $\begin{array}{l}\text { Platelet count }(/ \mathrm{cu} \mathrm{mm}) \\
\text { Median }(\mathrm{IQR} 75,25)\end{array}$ & $\begin{array}{c}89,000 \\
(227,000,38,000)\end{array}$ & $\begin{array}{c}337,000 \\
(422,250,275,250)\end{array}$ & $<0.005$ \\
\hline $\begin{array}{l}\text { Plateletcrit }(\%) \\
\text { Median (IQR 75,25) }\end{array}$ & $\begin{array}{c}0.104 \\
(0.198,0.035) \\
\end{array}$ & $\begin{array}{c}0.258 \\
(0.319,0.217) \\
\end{array}$ & $<0.005$ \\
\hline $\begin{array}{l}\text { Mean platelet volume }(\mathrm{fl}) \\
\text { Mean } \pm \mathrm{SD}\end{array}$ & $8.92 \pm 1.38$ & $7.82 \pm 0.89$ & $<0.005$ \\
\hline $\begin{array}{l}\text { Platelet distribution width (\%) } \\
\text { Mean } \pm \mathrm{SD}\end{array}$ & $17.32 \pm 1.32$ & $16.50 \pm 0.51$ & $<0.005$ \\
\hline
\end{tabular}

Age distribution was comparable in both groups with children aged $<5$ yrs being the majority age group. Median duration of hospital stay of cases $(\mathrm{n}=151)$ was 8 days (IQR 75, 25=14,6days).
Statistically significant difference $(\mathrm{p}<0.005)$ was noted in platelet count, plateletcrit, MPV and PDW among the cases and controls. Laboratory parameters among cases are shown in Table 2.

Table 2: Laboratory parameters among cases $(n=151)$

\begin{tabular}{|c|c|c|c|c|}
\hline Laboratory parameter & Sepsis $(n=76)$ & Severe sepsis $(n=36)$ & Septic shock $(n=39)$ & $p$ value \\
\hline $\begin{array}{l}\text { Platelet count }(/ \mathrm{cu} \mathrm{mm}) \\
\text { Median (IQR } 75,25)\end{array}$ & $\begin{array}{c}143,000 \\
(366,000,69,750)\end{array}$ & $\begin{array}{c}63,000 \\
(130,000,28,250)\end{array}$ & $\begin{array}{c}41,000 \\
(94,000,27,000)\end{array}$ & 0.001 \\
\hline $\begin{array}{l}\text { Plateletcrit }(\%) \\
\text { Median (IQR 75,25) }\end{array}$ & $\begin{array}{c}0.127 \\
(0.303,0.067)\end{array}$ & $\begin{array}{c}0.059 \\
(0.119,0.029)\end{array}$ & $\begin{array}{c}0.037 \\
(0.110,0.027)\end{array}$ & 0.001 \\
\hline $\begin{array}{l}\text { Mean platelet volume }(\mathrm{fl}) \\
\text { Mean } \pm \text { SD }\end{array}$ & $8.76 \pm 1.42$ & $9.08 \pm 1.48$ & $9.09 \pm 1.18$ & 0.344 \\
\hline $\begin{array}{l}\text { Platelet distribution width (\%) } \\
\text { Mean } \pm \text { SD }\end{array}$ & $17.3 \pm 1.25$ & $17.39 \pm 1.58$ & $17.31 \pm 1.24$ & 0.942 \\
\hline $\begin{array}{l}\text { C-reactive protein }(\mathrm{mg} / \mathrm{L}) \\
\text { Median (IQR } 75,25)\end{array}$ & $\begin{array}{c}85.15 \\
(170.9,43.8) \\
\end{array}$ & $\begin{array}{c}147.15 \\
(280.2,66.0)\end{array}$ & $\begin{array}{c}127.10 \\
(245.0,47.5)\end{array}$ & 0.071 \\
\hline $\begin{array}{l}\text { Total leucocyte count (/cu mm) } \\
\text { Median (IQR 75,25) }\end{array}$ & $\begin{array}{c}12,750 \\
(21,300,5150) \\
\end{array}$ & $\begin{array}{c}15,750 \\
(22,325,4625)\end{array}$ & $\begin{array}{c}12,600 \\
(19,200,4200)\end{array}$ & 0.480 \\
\hline
\end{tabular}

Among the sepsis group, platelet count and plateletcrit were able to predict the severity of sepsis $(p=0.001)$. No significant difference was noted in MPV, PDW, C-reactive protein (CRP) and total leucocyte count (TLC) values among different sepsis groups.

Table 3 shows the laboratory parameters on day 1 and outcome of the 151 children with sepsis.

Table 3: Laboratory parameters on day 1 and outcome of children with sepsis $(n=151)$

\begin{tabular}{|c|c|c|c|}
\hline Laboratory parameter & Survivors $(n=109)$ & Non survivors $(n=42)$ & $p$ value \\
\hline $\begin{array}{l}\text { Platelet count }(/ \mathrm{cu} \mathrm{mm}) \\
\text { Median (IQR } 75,25)\end{array}$ & $\begin{array}{c}109,000 \\
(315,500,53,000)\end{array}$ & $\begin{array}{c}56,500 \\
(115,250,28,500)\end{array}$ & 0.003 \\
\hline $\begin{array}{l}\text { Plateletcrit }(\%) \\
\text { Median (IQR 75,25) }\end{array}$ & $\begin{array}{c}0.091 \\
(0.262,0.044)\end{array}$ & $\begin{array}{c}0.052 \\
(0.113,0.029)\end{array}$ & 0.004 \\
\hline $\begin{array}{l}\text { Mean platelet volume (fl) } \\
\text { Mean } \pm \text { SD }\end{array}$ & $8.92 \pm 1.45$ & $8.93 \pm 1.19$ & 0.982 \\
\hline $\begin{array}{l}\text { Platelet distribution width }(\%) \\
\text { Mean } \pm \text { SD }\end{array}$ & $17.22 \pm 1.27$ & $17.58 \pm 1.43$ & 0.162 \\
\hline $\begin{array}{l}\text { C-reactive protein }(\mathrm{mg} / \mathrm{L}) \\
\text { Median (IQR } 75,25)\end{array}$ & $\begin{array}{c}88.4 \\
(183.5,46.6)\end{array}$ & $\begin{array}{c}159.7 \\
(288.9,46.1)\end{array}$ & 0.087 \\
\hline $\begin{array}{l}\text { Total leucocyte count (/cu mm) } \\
\text { Median (IQR } 75,25)\end{array}$ & $\begin{array}{c}13,000 \\
(21,150,5200)\end{array}$ & $\begin{array}{c}11,150 \\
(22,100,4175)\end{array}$ & 0.504 \\
\hline
\end{tabular}


Among survivors and non-survivors with sepsis, (Table 3) statistically significant differences were observed with platelet count and plateletcrit values done on day 1 of admission ( $p$ values 0.003 and 0.004 respectively).
The relationship between the severity of thrombocytopenia and outcome of children with sepsis is shown in Table 4.

Table 4: Relationship between severity of thrombocytopenia and outcome of children with sepsis

\begin{tabular}{|l|c|c|c|}
\hline $\begin{array}{c}\text { Children with thrombocytopenia } \\
\text { on day } \mathbf{1}(n=102)\end{array}$ & $\begin{array}{c}\text { Survivors with } \\
\text { thrombocytopenia }(\mathrm{n}=68)\end{array}$ & $\begin{array}{c}\text { Non survivors with } \\
\text { thrombocytopenia }(n=34)\end{array}$ & $\boldsymbol{p}$ value \\
\hline Mild $(\mathrm{n}=55)$ & $41(74.5 \%)$ & $14(25.5 \%)$ & \multirow{2}{*}{0.151} \\
\hline Moderate $(\mathrm{n}=33)$ & $18(54.5 \%)$ & $15(45.5 \%)$ & \\
\hline Severe $(\mathrm{n}=14)$ & $09(64.3 \%)$ & $05(35.7 \%)$ & \\
\hline
\end{tabular}

One hundred and two out of 151 cases had thrombocytopenia on day 1 of admission. 34/42 non-survivors and 68/109 survivors had thrombocytopenia on day 1 . Severity of thrombocytopenia on dayl (table 4) was not able to predict the mortality in the study group $(\mathrm{p}=0.151)$. Platelet counts done before discharge or death showed thrombocytopenia in 38 children (14 survivors and 24 non-survivors). Fourteen out of 109 survivors had mild thrombocytopenia before discharge. Out of 42 non-survivors, repeat platelet count could be done only in 24 as 18 cases expired before the second platelet count could be done. On comparison of thrombocytopenia before discharge/death in survivors and non-survivors, survivors had only mild thrombocytopenia whereas $66.6 \%$ of non survivors had moderate or severe thrombocytopenia, with a statistically significant difference $(\mathrm{p}=0.006)$.

Receiver operating characteristic (ROC) analysis in children with sepsis, a cut off value for the platelet count of 158500 cells/ cu.mm showed sensitivity of $69 \%$ and specificity of $100 \%$ in predicting sepsis. Mean platelet volume, $8.35 \mathrm{fl}$ as cut off value showed sensitivity of $64 \%$ and specificity of $81 \%$ in predicting sepsis. Platelet distribution width $17.05 \%$ as cut off value showed sensitivity of $58 \%$ and specificity of $87 \%$ in predicting sepsis.

\section{Discussion}

Diagnosing sepsis and its severity early would help clinicians decide on the appropriate treatment options and help alleviate morbidity and decrease mortality. Cheaper and reliable parameters are the need of the hour to facilitate the management of children with sepsis.

In the present study, the male to female ratio was 1.5:1, which is similar to the study done by Bind L, et $a l^{9}$. Majority of the children with sepsis were aged less than 5 years, reflecting the vulnerability of younger children to life threatening illnesses. In a study by Todi $\mathrm{S}$, et $a l^{10}$, children aged 2-8 years were most commonly affected. Severe sepsis and septic shock combined were seen in $49.6 \%$ of cases and was similar to the study by Carvalho, et $a l^{11}$.
Mortality in the current study was $27.8 \%$ of cases whereas it ranged between 16.8 to $31.8 \%$ in a study by Marti, et $\mathrm{al}^{12}$. Being a tertiary centre, around $1 / 3^{\text {rd }}$ of the cases were referred very late (evident by the fact that 14 out of 42 non-survivors succumbed within 24 hours) which was the prime reason for the higher mortality rates in the current study.

The difference in platelet indices (Plateletcrit, MPV and PDW) between cases and controls was found to be statistically significant $(p<0.005)$. In a study done by Guclu, et $a l^{4}$, the difference in MPV and PDW between cases and controls were found to be statistically significant $(p<0.001)$. On day 1 , thrombocytopenia was observed among $67.5 \%$ $(102 / 151)$ of cases, which is similar (59\%) to study by Guclu, et $a l^{4}$. A statistically significant difference was observed in platelet counts and PCT ( $p 0.003$ and 0.004 respectively) among cases with sepsis, severe sepsis and septic shock, with lower levels signifying higher severity. In a study by Agarwal, et al high mortality was observed in children with thrombocytopenia $(\mathrm{p}=0 \text { l. } 0053)^{13}$. Median platelet count and PCT were significantly low among non survivors when compared to survivors whereas CRP and TLC did not show a significant relationship. Thus, platelet count and plateletcrit (with an advantage over CRP and TLC) can be useful in predicting the mortality. Other platelet indices were not statistically different among survivors and non survivors. These observations are in contrast to Lee MJ, et al where MPV and PDW was found to be significantly high in non survivors ${ }^{14}$. In the present study, severity of thrombocytopenia on day 1 did not show any relationship with outcome of children with sepsis; however, severity of thrombocytopenia prior to discharge or mortality showed platelet count to be significantly lower among non survivors $(p=0.006)$.

Platelet indices (PDW, plateletcrit, MPV) would help as a reliable, low cost laboratory parameters in diagnosing and assessing the severity of sepsis in children. This would help in instituting early, appropriate therapy and thereby, improving morbidity and mortality of this global problem. 


\section{Conclusions}

In the present study, plateletcrit, mean platelet volume, platelet distribution width and platelet count showed statistically significant relation in children with sepsis when compared to controls. With regard to predicting mortality, platelet count and plateletcrit showed statistically significant lower values among non survivors when compared to survivors.

\section{References}

1. Proulx F, Fayon M, Farrell CA, Lacroix J, Gauthier M. Epidemiology of sepsis and multiple organ dysfunction syndrome in children. Chest 1996; 109:1033-7.

https://doi.org/10.1378/chest.109.4.1033

PMid: 8635327

2. Watson RS, Carcillo JA. Scope and epidemiology of paediatric sepsis. Pediatric Critical Care Medicine 2005; 6(3):3-4.

https://doi.org/10.1097/01.PCC.00001612 89.22464.C3

PMid: 15857554

3. Munford RS, Suffredini AF. Sepsis, severe sepsis, and septic shock. In: Mandell GL, Bennett JE, Dolin R, editors. Mandell, Douglas, and Bennett's Principles and Practice of Infectious Diseases. $7^{\text {th }}$ ed. Philadelphia: Churchill Livingstone; 2010. p 987-1010. https://doi.org/10.1016/B978-0-443068393.00070-9

4. Van der Lelie J, Von dem Borne AE. Increased mean platelet volume in septicaemia. Journal of Clinical Pathology 1983; 36:693-6. https://doi.org/10.1136/jep.36.6.693

5. Guclu E, Durmaz Y, Karabay O. Effect of severe sepsis on platelet count and their indices. African Health Sciences 2013; 13(2):333-8.

https://doi.org/10.4314/ahs.v13i2.19

6. Lubin BH. Reference values in infancy and childhood. In: Nathan DG, and Oski FA. Haematology of Infancy and Childhood. 2nd ed. Philadelphia PA: WB Saunders Co; 1981. p 1552-74.

7. Farias MG, Schunck EG, Dal Bo, De Castro. Definition of reference ranges for platelet distribution width (PDW): a local need. Clinical Chemistry and Laboratory Medicine 2010; 48(2):255-7.
https://doi.org/10.1515/CCLM.2010.035

PMid: 19958208

8. Thayse VG, Aguinaldo JD, Josiane PP. Platelet indices: Laboratory and clinical applications. Rev Bras Hematol Hemoter. 2011; 33(2):164-5. https://doi.org/10.5581/15168484.201100 40

PMid: 23284267 PMCid: PMC3520644

9. Bindl L, Buderus S, Dahlem P, Demirakca S, Goldner M, Hutb R, et al. Gender based differences in children with sepsis and ARDS. Intensive Care Medicine 2003; 29:1770-3.

https://doi.org/10.1007/s00134-003-1948Z

PMid: 12920510

10. Todi S, Chatterjee S, Bhattacharyya M. Epidemiology of severe sepsis in India. Critical Care 2007; 11(2):65. https://doi.org/10.1186/cc5225 PMCid: PMC4095119

11. Carvalho PR, Feldens L, Seitz EE, Rocha T, Soledade M, Trotta A. Prevalence of systemic inflammatory syndromes at a tertiary pediatric intensive care unit. Journal of Pediatrics 2005; 81(2):143-8. https://doi.org/10.2223/1320

12. Martin GS, Mannino DM, Eaton S, Moss M. The epidemiology of sepsis in the United States from 1979 through 2000. New England Journal of Medicine 2003; 348(16):1546-54. https://doi.org/10.1056/NEJMoa022139 PMid: 12700374

13. Agrawal S, Sachdev A, Gupta D, Chugh $\mathrm{K}$. Platelet counts and outcome in the paediatric intensive care unit. Indian Journal of Critical Care Medicine 2008; 12(3):102-08.

https://doi.org/10.4103/0972-5229.43678

PMid: 19742257 PMCid: PMC2738316

14. Kim $\mathrm{CH}$, Kim SJ, Lee MJ, Kwon YE, Kim YL, Park KS, et al. An increase in mean platelet volume from baseline is associated with mortality in patients with severe sepsis or septic shock. Plos One 2015; 10(3): 0119437.

https://doi.org/10.1371/journal.pone.0119 437

PMid: 25742300 PMCid: PMC4350997 